外リンパ瘻に続発した内リンパ水腫例

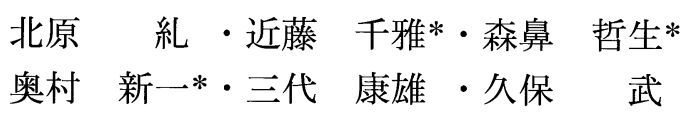

\title{
Management of Secondary Endolymphatic Hydrops Associated with Perilymphatic Fistula
}

\author{
Tadashi Kitahara, Yasuo Mishiro and Takeshi Kubo \\ (Osaka University) \\ Kazumasa Kondoh, Tetsuo Morihana and Shin-ichi Okumura \\ (Osaka Rosai Hospital)
}

\begin{abstract}
We report a 26-year-old male patient with vertiginous sensation and sensorineural hearing loss of high frequency in his left ear after breathing strongly through his nose and hearing a pop sound. Because of his persistent dizzy spells and progressive hearing loss, we diagnosed perilymphatic fistula and performed an exploratory tympanotomy. We closed both oval and round windows with fascia, although we could not find any obvious fistula during surgery, resulting in reduction of dizziness and prevention of progressive hearing loss.

One year after the operation, the patient came to complain about episodic vertigo with left fluctuating hearing loss. His audiogram showed left low tone sensorineural hearing deterioration and a glycerol test revealed endolymphatic hydrops in the left ear. we diagnosed secondary endolymphatic hydrops associated with perilymphatic fistula and performed endolymphatic sac drainage and steroid-instillation surgery. Follow-up for 6 months showed complete relief from vertigo and $11.3 \mathrm{~dB}$ hearing improvement.
\end{abstract}

Key words : endolymphatic hydrops, perilymphatic fistula, exploratory tympanotomy, endolymphatic sac drainage, steroids

はじめに

メニエール病の病態が内リンパ水腫であることは, わ が国の Yamakawa ${ }^{1)}$ および英国の Hallpike ら²)により 1938 年に世界で初めて報告された. 以来, メニエール病は原 因不明の内リンパ水腫と定義されてきた。一方, Schuknecht $ら^{3)}$ は1983年に内リンパ水腫の分類を提唱し, 外傷に起因する acquired type の内リンパ水腫が存在する ことを報告した。外リンパ瘻も外リンパ虚脱から続発性 内リンパ水腫を生じ得る疾患と考えられるが, 実際の報 告は比較的まれである4)5). われわれは外リンパ瘻疑いに
て試験的鼓室開放術を施行した後, 回転性めまいととも に低音部の感音難聴が変動するなどのメニエール病様症 状に移行したため, 内リンパ霊開放術を施行し, 症状の 改善をみた症例を経験したので, 若干の考察とともに報 告する.

症 例
症例 : 26 歳, 男性.
主訴 : 左耳鳴, 左難聴, 回転性めまい.
既往歴 : 特記すべきことなし.

\footnotetext{
大阪大学大学院感覚器外科学耳鼻咽喉科

*大阪労災病院耳鼻咽喉科
} 


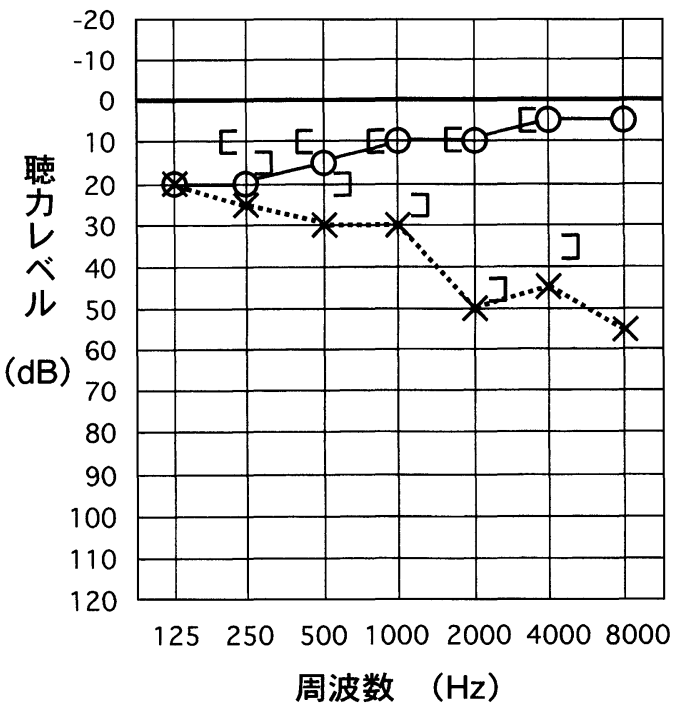

図 1 初診時の標準純音聴力図

左耳聴力は 4 分法で $35.0 \mathrm{~dB}$ の高音漸傾型感音難聴を認め た.

○印：右健側耳， ×印：左患側耳.

家族歴：特記すべきことなし.

現病歴: 平成 11 年 4 月, 鼻かみ時にポップ音あり, 同 時に左耳鳴，耳閉感が生じるともに回転性めまいを自覚 した。 近医耳鼻咽喉科にて外リンパ瘻疑いと診断され, 当科紹介受診となった.

初診時所見：左鼓膜所見は正常範囲.

聴力検查 : 標準純音聴力検查では, 左耳聴力は 4 分法 で 35.0dB の高音漸傾型感音難聴を認めた（図 1).

画像所見：中耳ターゲット CT の $1 \mathrm{~mm}$ 厚水平断によ り，特に中耳腔に浸出液なども認めず。また内耳道, 後 頭蓋窩に著変認めなかった。

平衡機能検查：注視，自発眼振は認めなかった。左下 頭位にて弱い右向きの水平眼振を認めた. また右向きの 頭振後眼振を認めた。瘦孔現象は認めなかった。温度刺 激検査で左軽度 CP を認めた。

以上のことから，厚生省（現，厚生労働省）特定疾患 急性高度難聴調査班（平成 2 年度）の診断基準（表 1）に より左外リンパ瘻疑いと診断し ${ }^{6)}$, 平成 11 年 6 月局所麻 酔下にて左試験的鼓室開放術を施行した。

手術所見：局所麻酔下に，左耳後部切開から外耳道皮 膚を一部後壁より剥離し，外耳道後壁を削開した後，耳 小骨および両内耳空を術野明視下に置いた，術中，腹圧 およびバルサルバそれぞれの負荷後においても, 中耳腔

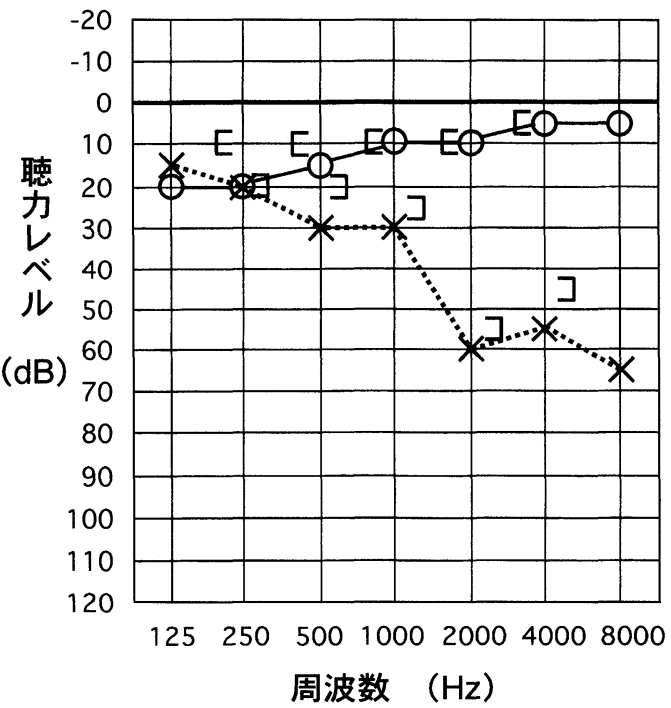

図 2 試験的鼓室開放術 2 週後の純音聴力図 左耳聴力は 4 分法で $37.5 \mathrm{~dB}$ と難聴の進行は停止した。 ○印：右健側耳, $\times$ 印：左患側耳.

表 1 外リンパ㾞の診断基準

（厚生省平成 2 年度特定疾患急性高度難聴調查班）

\section{確実例 :}

手術 (鼓室開放術)，内視鏡などにより前庭空，蝸牛空の いずれか，または両者より外リンパ，あるいは髄液の漏出 を確認できたもの，また㾞孔の確認できたもの.

疑い例 :

髄液圧, 鼓室圧の急激な変動を起こすような誘因の後に耳 閉感, 難聴, 耳鳴, めまい, 平衡障害などが生じた (注 1〜8).

注 1 力み, 重いものを持ち上げた, 鼻かみ, 努責, 潜水, 飛行機旅行などが誘因となる。

注 2 症状は全部揄わなくてもよい. いずれか一つのこと もある。

注 3 パチッといら音（pop）を伴うことがある。

注 4 再発することがある.

注 5 感音難聴が数時間, 数日かけて生じた．時に変動す る.

注 6 急性発症の難聴があって“水の流れるような耳鳴”あ るいは“水の流れる感じ”がある.

注 7 外耳・中耳の加圧・減圧などでめまいを訴える.

注 8 動摇感が持続し，患側下で頭位眼振がみられる。

に外リンパ液の明らかな漏出所見は観察し得なかった. 両内耳空付近の粘膜を除去した後，筋膜を敷きフィブリ ン糊で固定した，さらに，鼓膜，外耳道皮膚を元に戻し 手術を終えた。

術後経過：術後 2 週の段階で, 左耳聴力は 4 分法で $37.5 \mathrm{~dB}$ と難聴の進行は停止し（図 2), 浮動感も体動時 以外にはほとんど感じられなくなるまでに至った。しか 


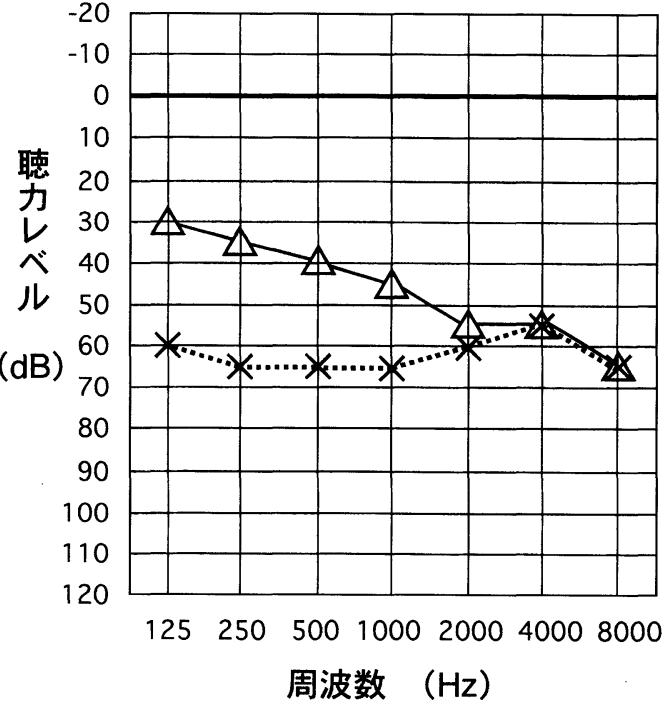

図 3 試験的鼓室開放術 18 カ月後およびグリセロール・テスト 後の純音聴力図

左耳聴力は 4 分法 $63.8 \mathrm{~dB}$ と前回術後聴力よりさらに低音 部の感音難聴が進行した.

グリセロール・テストは左側にて陽性であった。

×印 : 左患側耳 (術 18 力後), $\triangle$ 印 : 左患側耳 (グリセ ロール・テスト後).

しながら, 平成 12 年 12 月（術後 18 カ）に再び回転性 めまいおよび左耳鳴, 変動する左難聴を自覚するように なったため, 当科を再診した。

再診時所見：視診上, 左鼓膜, 外耳道に著変なし.

聴力検查: 標準純音聴力検查では, 左耳聴力は 4 分法 $63.8 \mathrm{~dB}$ と前回術後聴力よりさらに低音部の感音難聴が 進行した。 グリセロール・テストは左側にて陽性であっ た（図 3).

平衡機能検查: 注視, 自発, 頭位眼振は認めなかった。 右向きの頭振後眼振を認めた. 㜢孔現象は認めなかった. 温度刺激検查で前回術前と同等の左軽度 $\mathrm{CP}$ を認めた。

以上により, 左外リンパ瘦に続発した内リンパ水腫と 診断した7). その後, めまい発作は 2 力月に 1 回程度の割 合で起こり，それに伴って聴力変動も生じた（図 4). ソソルビドにて保存的治療を試みるも抵抗を示したた め, 平成 13 年 12 月全身麻酔下にて左内リンパ囊高濃度 ステロイド插入術を施行した。

手術所見：術式の詳細はすでに報告したとおりであ る ${ }^{819)}$. 簡記すると, 全身麻酔下に広く乳突洞を削開し, $\mathrm{S}$ 状静脈洞前方の後頭蓋窩脳硬膜を後半規管後下方まで 十分露出し，内リンパ囊を明視下に置いた。 囊後下縁に

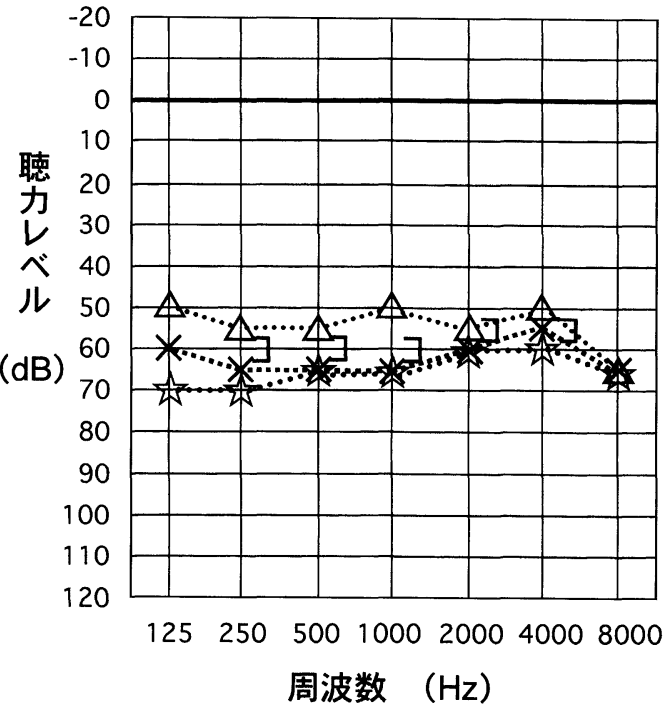

図 4 内リンパ囊開放術前の聴力変動

$\times$ 印: 平成 12 年 12 月 12 日（骨導も表示）

$\triangle$ 印: 平成 13 年 4 月 10 日

级印：平成 13 年 10 月 9 日

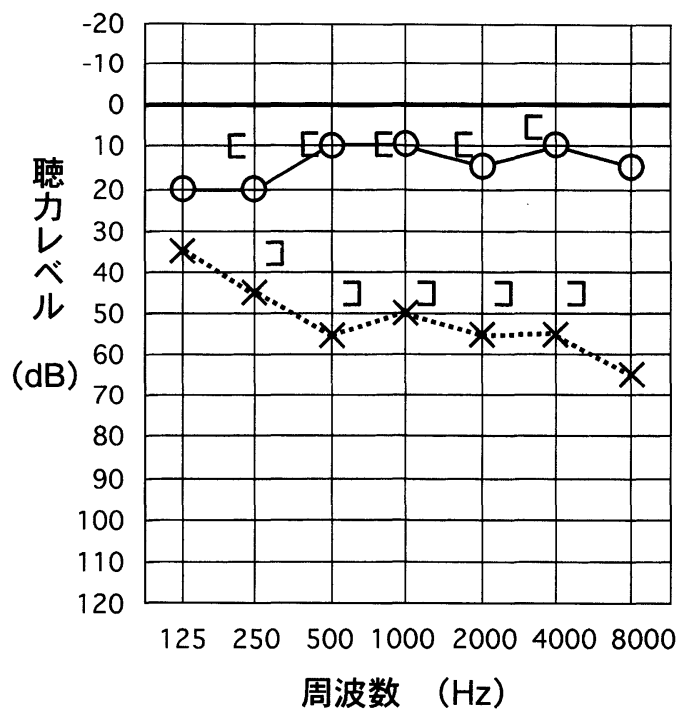

図 5 内リンパ囊高濃度ステロイド挿入術 6 カ月後の純音聴力 図

左耳聴力は 4 分法にて $52.5 \mathrm{~dB}$ と改善安定していた.

○印：右耳健側, $\times$ 印 : 左耳患側.

沿って切開を加え, 囊を乳突腔に開放し, 水溶性プレド ニゾロン塊を豪内腔に挿入溶解させた。 次いで，一端を 扇状，他端をフィブリン糊で棒状に固定した短冊状ゼル フィルム 5 枚重ねの束を作製し，一方の扇状端を内リン パ囊内腔に挿入し，その間隙と囊周辺に高濃度デキサメ 
タゾン加ゼルスポンジを留置し，その長期徐放効果を期 待しつつ周囲をフィブリン糊にて被覆固定した。他方の ゼルフィルム束棒状端は乳突洞削開前縁にフィブリン糊 で固定した。乳突洞創腔には術後感染予防のため抗生剂 加ゼルスポンジを置き, 皮膚切開を縫合し, 手術を終え た.

術後経過: 術後 6 力月で, 回転性めまいは完全に消失 しており, 左耳聴力も 4 分法にて $52.5 \mathrm{~dB}$ と改善安定し ていた（図 5).

\section{考 察}

本症例は平成 11 年の当科初診時, 急な腹圧負荷の後に ポップ音があり, 回転性めまいとともに左耳鳴, 左高音 部の難聴が生じた。これらの臨床症状から，本症例は厚 生省（現，厚生労働省）の診断基準により外リンパ瘦疑 いと診断された ${ }^{6)}$. 外リンパ瘦の確定診断はあくまでも 試験的鼓室開放による直接の外リンパの漏孔の確認であ り，その意味で本症例は手術後においても疑い例の域を 越え得なかった。過去の報告において，外リンパ瘦に対 する瘦孔閉鎖術は聴力の改善に対してはあまり期待でき ないが，めまい平衡障害の改善に対しては有効であると 意見の一致をみている10) 13)。本症例においては，手術 により左難聴の改善はなかったものの悪化進行は停止 し，回転性めまい発作の消失および体動時の浮動感も軽 減した。 このような術後の良好な臨床経過が得られたこ とからも，本症例は外リンパ㿉であったと推察される. 術中外リンパ瘦が確認できなかったことについては，す でに瘦孔が閉鎖していた可能性や間欠的に漏出するタイ プであった可能性は否定できない。このように鼓室試験 開放時に外リンパの瘦孔漏出を確認し得ない確率は，自 験例でも $62 \%$ とかなり高率に存在する ${ }^{13)}$. 瘦孔漏出確認 は腹圧のかけ方にも影響されるので，バルサルバ，トレ ンデンブルグとの併用などを工夫する必要があったとも 考えられるが，術後難聴の増悪をみる例があるとの報告 もあり注意を要する ${ }^{6)}$. 術前・術中の確定診断法につい てはなかなか困難であり, 術前蛍光色素静脈内投与14) や 経鼓膜的内視鏡 ${ }^{15)}$ など種々の工夫は試みられているがい まだ実用には至らず，今後のこの分野の研究発展に注目 したい.

本症例は平成 12 年の当科再診時, 回転性めまいととも に左耳鳴および左低音部聴力が変動し始め，グリセロー ル・テストも陽性であり，この段階で左内耳に内リンパ
水腫が存在することが推察される7)。初診時にはグリセ ロール・テストは施行されておらずはっきりしたことは いえないが，初診時の聴力図および臨床経過から考えて も平成11年当初は左内リンパ水腫の存在はほぼ否定して 良いと考える.さらに, 特発性メニエール病の側頭骨所 見として特徴的である後迷路蜂巣 ${ }^{16) 17)}$ および内リンパ霊 の発育不良 ${ }^{18)}$ に相反して, 本症例の術中所見として後半 規管後下方の蜂巣発育はきわめて良好であり, 内リンパ 囊む大きく栄養血管も比較的豊富であった. 以上のこと から，本症例の内リンパ水腫はその発生素因は生来のも のではなく, 外リンパ㿉による外リンパ虚脱から 2 次的 に生じたと考えるのが妥当である. 外リンパ瘦から続発 的，持続的に内リンパ水腫が生じる原因については，外 リンパ組成の低張性変化 ${ }^{19)}$ や膜迷路のひきつれ 20) が推 定されているが，今後のこの分野の研究発展に注目した い. また, 外リンパ瘦受傷から内リンパ水腫由来と考え られるめまい発作発症までの期間は，本症例においては 約 18 月と比較的長期であった. 問診によると，この時 期は患者が外リンパ瘦術後の社会復帰を果たし本格的に 就労を始めて間もない頃であり, めまい発作発症には上 記の物理的な変化に加え，ストレスによる内リンパ過剩 生産などに起因する可能性も否定できないと考えられ た。

Schuknecht ら ${ }^{3)}$ は 1983 年に内リンパ水腫の分類を提唱 し, 外傷に起因する acquired type の内リンパ水腫が存在 することを報告した．外リンパ瘦受傷による外リンパ虚 脱から 2 次的に内リンパ水腫を生じたと考えられる本症 例もこの分類に属すと考えられるが，実際の報告は比較 的まれである ${ }^{4) 5}$. Fitzgerald ${ }^{21)}$ は最近の総説で, 9 年間 64 例の外リンパ瘦確実例自験例を踏をえて, 外リンパ瘦と メニエール病の鑑別診断, 治療の難しさについて論じて いる，その論文ではまず瘦孔閉鎖術のみ施行した症例は 40 例で，難聴あるいは平衡失調の改善をみたものが 23 例 $57.5 \%$ であり, 改善をみなかったものあるいは悪化し たものが 17 例 $42.5 \%$ であった. 後者 17 例のうち内リン パ囊手術を施行したものが 10 例で, らち 7 例に難聴ある いは平衡失調の改善をみたといら。これらのことから， 後者17例については全例とはいわないまでも少なくとも 一部に本症例同様の続発性内リンパ水腫例が含まれてい たと考えられる．したがって，外リンパ瘦に続発する内 リンパ水腫例は少なからず存在し，それが疑われる症例 に対しては積極的に瘦孔閉鎖に加えて内リンパ䪄手術を 
考慮する必要があると思われた。

\section{まとめ}

外リンパ瘦にて試験的鼓室開放術を施行した後, 回転 性めまいとともに低音部の感音難聴が変動するなどのメ ニエール病様症状に移行したため, 内リンパ囊開放術を 施行し，症状の改善をみた症例を経験した。

本症例は外リンパ瘦による外リンパ虚脱から 2 次的に 内リンパ水腫が生じたと考えられ，外リンパ瘦は続発性 内リンパ水腫の一因となり得ると考えられた。

\section{参考文献}

1) Yamakawa $K$ : The pathology of a labyrinth with Meniere's disease. Jpn J Otol $44: 2310 \sim 2312,1938$.

2) Hallpike CS and Cairns $H$ : Observations on the pathology of Meniere's syndrome. J Laryngol Otol $53: 625 \sim 655,1938$.

3) Schuknecht HF and Gulya AJ : Endolymphatic hydrops; an overview and classification. Ann Otol Rhinol Laryngol Suppl $106: 1 \sim 20,1983$

4) Lehrer JF, Quraishi AU and Poole DC : The role of endolymphatic sac surgery in the management of secondary endolymphatic hydrops associated with perilymphatic fistulas; preliminary observations. Am J Otol $8: 93 \sim 95,1987$.

5）柳原尚明, 比野平恭之, 古田口裕, 他: 外リンパ瘦が原因 と考えられた内リンパ水腫例. Otol Jpn 11：488, 2001.

6) 野村恭也 : 外リンパ瘦の病因, 病態, 診断, 治療法. 耳鼻 咽喉科・頭頸部外科クリニカルトレンド（野村恭也, 本庄 䉷, 平出文久編). 中山書店, 東京, $60 \sim 63$ 頁, 1996.

7）厚生省特定疾患前庭機能異常調查研究班：メニエール病の 診断・検查・治療に関する資料. Equilibrium Res Suppl 11 : $69 \sim 71,1995$.

8) Kitahara T, Takeda N, Mishiro Y, et al. : Effects of exposing the opened endolymphatic sac to large doses of steroids to treat intractable Meniere's disease. Ann Otol Rhinol Laryngol $110: 109 \sim 112,2001$.

9）北原 糺, 武田憲昭, 近藤千雅, 他：メニエール病に対す る内リンパ囊高濃度ステロイド挿入術による長期治療成
績. 日耳鼻 $104 ： 738 ～ 743 ， 2001$.

10) Seltzer $S$ and McCabe BF : Perilymphatic fistula; the Iowa experience. Laryngoscope $96: 37 \sim 49,1986$.

11）暁 清文, 佐伯忠彦, 西原信成: 外傷性めまい症例におけ る外リンパ瘦の検討. Equilibrium Res $46: 160 \sim 164,1987$.

12）小川 郁, 神崎 仁: 外リンパ瘦の臨床像. Otol Jpn $1: 1$ $\sim 8,1991$.

13）北原 糺, 久保 武, 楢村裕美, 他: 外リンパ瘦における 平衡障害の予後. Equilibrium Res Suppl 9:98〜 101, 1993.

14) SymsIII CA, AtkinsJr JS and Murphy TP : The use of fluorescein for intraoperative confirmation of perilymph fistula- a preliminary report. Surgery of the Inner Ear (ed by Arenberg IK). pp $379 \sim 381$, Kugler Publications, 1991.

15）高橋真理子，渡邊暢浩，村上信五：内視鏡にて診断しえた 外リンパ瘦の一例. Otol Jpn 11:487, 2001.

16) Stahle $J$ and Wilbrand $H$ : The vestibular aqueduct in patients with Meniere's disease. Acta Otolaryngol (Stockh) $78: 36 \sim$ 48, 1974.

17) Yazawa $Y$ and Kitahara $M$ : Computed tomographic findings around the vestibular aqueduct in Meniere's disease. Acta Otolaryngol Suppl (Stockh) $481: 88 \sim 90,1991$.

18) Yazawa $Y$, Suzuki M, Tanaka H, et al. : Surgical observations on the endolymphatic sac in Meniere's disease. Am J Otol 19: $71 \sim 75,1998$.

19) Juhn SK, Rybak LP and Fowlks WL: Transport characteristics of the blood-perilymph barrier. Am J Otol 3:392 396, 1982.

20) Nomura $Y$, Hara $M$, Young $Y H$, et al. : Inner ear morphology of experimental perilymphatic fistula. Am J Otol $13: 32 \sim 37$, 1992.

21) Fitzgerald DC : Perilymphatic fistula and Menierés disease; clinical series and literature review. Ann Otol Rhinol Laryngol $110: 430 \sim 436,2001$.
原稿受付：平成14年10月 1 日

原稿採択：平成14年12月 4 日

別刷請求先 : 近藤千雅

于591-8025 堺市長兽根町1179-3

大阪労災病院耳鼻咽喉科 